\title{
Why I . . . set up a hockey team
}

\section{Claire Hope tells Francesca Robinson how setting up a hockey team for her hospital colleagues has helped them to rediscover the joys of team sports}

\section{Francesca Robinson}

The BMJ

Claire Hope, a paediatric registrar at Musgrove Park Hospital, Taunton, feels that time for hobbies is often squeezed out by the pressures of a busy hospital job.

"At medical school we play lots of sports but then we become doctors and suddenly we don't have time for these activities anymore," she says. "So we lose the hobbies that gave us the leadership skills and the ability to be team players that the medical schools recruited us for."

A hockey player since the age of 12, Hope played for her medical school but later found she was unable to combine the sport with her medical training. She has always been passionate about the game so when a friend suggested she made up a hospital team for a local, friendly mixed hockey league, Hope jumped at the opportunity.

When she put the word around by email she found her colleagues were equally enthusiastic. She easily signed up 20 people, giving her enough players to make up an 11 strong team most weeks.

The team comprises a mix of healthcare professionals, including junior doctors, consultants, dietitians, and physiotherapists, who have an array of hockey skills, from those who haven't played since school to others who have played at international level. This wide range of experience doesn't matter, Hope says, because the aim is to have fun and let off steam and while enjoying the camaraderie of playing in a team.

"People in the team work at different levels and in different disciplines in the hospital but on the hockey pitch everyone is just the person you're passing to or receiving from," she says.

"Playing together is a great leveller and it flattens the hierarchy. For example, we have a brilliant, well respected consultant from the surgical team who I'd never met socially before we played hockey together. Three weeks later we passed each other in the corridor and she saluted me and said, 'Hi, Boss'!"

Playing hockey can be a great way of winding down and relieving stress, Hope has found. "In the pub, instead of moaning about shifts or how tired we are, we can just chill out and socialise with each other, congratulating each other on some awesome goals or laughing about some awful defending," Hope says.

"As paediatricians we don't always work closely with the adult medical teams so it can be difficult to get to know our colleagues. I'm now playing hockey with people that I've been writing referral letters to or had phone conversations with who I had never previously met in five years working at the hospital."

Hope has found it easy to keep the team going. She uses WhatsApp to communicate with members to ensure she has 11 players with a hockey stick for each match. There is a schedule of league fixtures for several months ahead, which gives players time to swap shifts if needed. With no commitment to training, membership fees, or formal kit, it makes it a lot easier and cheaper than joining a club.

"Members of the team have told me that not having played team sport since university has been really tough, and they're excited about coming out and playing with a group of likeminded people in a way that they haven't done for years," she says.

"It has been really fab helping reignite my colleagues' passion for sport and allowing them an easy platform to get playing again. If you're thinking about starting a team locally, I'd say just do it."

\section{How to set up your own sports team}

First choose your sport-some sports such as football and netball need less equipment and are easier to play

Consider the safety of players-do they need equipment such as shin pads or gum shields? Not having these may prevent someone from wanting to play

Find out if there's a local league. You can do this through organisations such as Go Mammoth, each sport's national governing body, or your local county council

Use the hospital's website or newsletter, Facebook, Twitter, or other social media to find potential players

Keep the commitment simple with no pressure to be available for every game. Have at least double the number of players your team needs and have a rotation system to ensure you have a full team

WhatsApp works better than emails for alerting team members to last minute changes to timings or venue

Organise regular socials to ensure the cohesion of the team

Anyone wanting advice on setting up a hockey team can contact Claire Hope on Twitter @babydrclaire

Published by the BMJ Publishing Group Limited. For permission to use (where not already granted under a licence) please go to http://group.bmj.com/group/rights-licensing/ permissions 